\title{
Role of Selenium and/ or Vitamin E in Preventing Some Pre-and Post-Partum Problems in Dromedary She Camels
}

\author{
*Howayda S. Belal, **Elmetwaly H.E. and ***Amer A.M. \\ *Biology of Reproduction Department, Animal Reproduction \\ Research Institute (ARRI), **Camel Research Department, Animal \\ Production Research Institute (APRI) And *** Animal Production \\ Research Institute, Agriculture Research Center, Dokki, Giza, Egypt.
}

\begin{abstract}
A total of 24 pregnant she camels were randomly assigned into four equal experimental groups, control group not supplemented with either selenium (Se) and/or vitamin E, organic selenium group was supplemented in the diet with $3.6 \mathrm{mg}$ Se/animal for 75 days, Vitamin E group was supplemented in the diet with $15 \mathrm{IU} / \mathrm{kg}$ DM of Vit. E. for 75 days, and selenium and vitamin E group was supplemented in the diet with $(3.6 \mathrm{mg}$ of Se/animal $+15 \mathrm{IU} / \mathrm{kg}$ $\mathrm{DM}$ of Vit. $\mathrm{E}$ for 75 days. The supplementation was done at one month before calving at calving and one month after calving.

Blood samples were collected 4 weeks postpartum. Some blood biochemical parameters such as protein profile parameters and thyroid hormones. Oxidative stress parameters as Malondialdehyde (MDA), glutathione peroxidase $\left(\mathrm{GP}_{\mathrm{X}}\right)$, and total antioxidant capacity (TAC) were measured. Results showed increase in protein profile parameters in all treated groups than control one. Reduce activity of MDA in all treated groups. Meanwhile, there was significant increase in both GPx activity and TAC postpartum in all treated groups compared to the control. A significantly increase in the concentrations of triiodothyronine hormone $\left(\mathrm{T}_{3}\right)$ in all treated groups compared to control ones.
\end{abstract}

\section{Key words:}

Dromedary she camels, Selenium, Vitamin E, protein profile, thyroid hormones, oxidant and antioxidant parameters.

\section{Introduction}

Camels (Camelus dromedaries) considered as a vital species of livestock with good source of meat, milk and wool beside they can live in arid and semi-arid harsh environment (Faye et al., 2013). Vitamin $E$ is a fat-soluble vitamin and is not synthesized in the rumen. Therefore, vitamin $\mathrm{E}$ requirement must be provided in the animal feed. The 
predominant action of vitamin $\mathrm{E}$ against oxidation in the biological system via different mechanisms, including suppressing the ROS formation by inhibition of enzymes that contribute to the free radical production (Baraka, 2012), upregulating/protecting antioxidant defense, or directly scavenging reactive oxygen species (Brunetti, et al., 2013). Selenium (Se) is an essential trace element, reducing tissue peroxides and stimulating immune response (Pourjafar et al., 2014). Interaction with vitamin $\mathrm{E}$ is sometimes synergistic and sometimes partially substitutive to minimize cellular damage caused by endogenous free radicals (Ali et al., 2018). Additionally, Aghwan et al., (2016) denoted that, vitamin $\mathrm{E}$ and $\mathrm{Se}$ are considered as essential components of the antioxidant defense mechanisms, and play a critical role in the growth, the function of the immune system, and in the improvement of the animal's reproduction via their share in the critical enzymatic reactions (Maraba et al., 2018).

Se and Vit E supplementation during the transition period has been successfully used to improve the physiological performance of female dromedary camels as indicated by increasing serum proteins parameters, and enhancing the intracellular antioxidant status, which was reflected positively on the metabolic activity of pregnant dromedary camels (Ahmed and Elkhair, 2019). Selenium is also required for the conversion of thyroxine $\left(\mathrm{T}_{4}\right)$ into the more active triiodothyronine $\left(\mathrm{T}_{3}\right)$ via the enzyme type 4 deiodinase (Sethy et al., 2015).

Selenium supplementation reduces postpartum reproductive disorders like ovarian cysts and metritis (Mehdi and Dufrasne, 2016). Se also plays an important role in udder health, preventing clinical and subclinical mastitis (Machado et al., 2013).

\section{Material and methods}

The study was conducted in Animal Production Research Institute (APRI), camel farm at Mattrouh governorate, Egypt.

Animals:

Twenty-four apparently clinically healthy pregnant she camels, aged 5-12 years, number of parities (1-5), and weighing $400-650 \mathrm{~kg}$ were used in the present study. Experimental animals were housed in semi opened pens.

\section{Experimental design:}

The she camels were divided randomly into 4 equal groups, with each group containing 6 animals in each.

Control group: she camels were not supplemented with $\mathrm{Se}$ and / or Vit. E. 
Se-Organic group: she camels supplemented with organic selenium $\quad 3000 \quad \mathrm{mg} / \mathrm{kg}$ (alkosel®3000, Lallemand Animal Nutrition, Canada). This product is an inactivated whole cell yeast (Saccharomyces cerevisiae) produced by growing yeast in the presence of measured amounts of selenium salts. Live yeast cells absorb selenium and biochemically transform it into selenoproteins (selenomethionine). Organic selenium supplemented to each camel was $1.2 \mathrm{~g}$ of organic compound per day for 75 days. This quantity corresponded to a daily offer of $3.6 \mathrm{mg} \mathrm{Se} / \mathrm{animal}$. The selenium organic was in powder form and given daily by putting the powder in a date (Faye et al., 2013).

Vit. E group: she camels were received $15 \mathrm{IU} / \mathrm{kg} \mathrm{DM}$ of $\alpha$ tocopherol acetate/camel (MultiVeta-October, Egypt) for 75 days (one month before calving, at calving, and one month after calving in diet (Faye et al., 2013).

Se organic and Vit E group: she camels were supplemented with $3.6 \mathrm{mg}$ from organic $\mathrm{Se}+15$ IU/kg DM $\alpha$-tocopherol acetate for 75 days (one month before calving, at calving and one month after calving) in a date.

\section{Feeding:}

Experimental she camels were fed diet in pregnancy and lactation in summer season, composed of concentrates feed mixture $(12 \%$ crude protein and $70 \% \mathrm{TDN})(5 \mathrm{~kg} / \mathrm{head} /$ day $)$ in addition to a good quality roughage material that were alfalfa hay $(2 \mathrm{~kg} / \mathrm{head} /$ day $)$ and rice straw $(5 \mathrm{~kg} / \mathrm{head} / \mathrm{day})$. In winter season, concentrates feed mixture (12\% crude protein and $70 \%$ TDN) (3.5kg/head/day), berseem $(20 \mathrm{~kg} / \mathrm{head} /$ day $)$ and rice straw $(5 \mathrm{~kg} / \mathrm{head} / \mathrm{day})$. All animals had a free access to drinking water.

\section{Blood sampling:}

Blood samples were collected from all dams at one month postpartum. Ten $\mathrm{ml}$ of blood was collected in sterile glass test tubes without anticoagulant through puncture of the jugular vein using a sterile needle. The collected blood samples were let to coagulate, and centrifuged at $3000 \mathrm{rpm}$ for $20 \mathrm{~min}$. The harvested serum was kept at $20^{\circ} \mathrm{C}$ until evaluation.

\section{Biochemical analysis:}

The determination of serum total proteins and albumin were done according to Doumas et al. (1971). Serum globulins were calculated by subtracting the values of [albumin] from that of [total protein]. Determination of MDA activity was conducted by the method developed by Okhawa et al. (1979). GPX activity was determined by the method of Flohe and Gunzler (1984) and Total antioxidant capacity (TAC) was determined 
by the methods of Koracevic and Koracevic (2001). Determination of $\mathrm{T} 3$ and $\mathrm{T} 4$ were carried out according to Braveman (1996).

\section{Reproductive parameters:}

Data regarding reproductive performances of all supplemented groups of she camels were recorded during postpartum period (up to 75 days after calving). These parameters include the following: retained placenta, ovarian cyst, repeat breeder, abortion, early embryonic death, metritis and mastitis.

\section{Statistical analysis:}

All data were subjected to statistical analysis according to Snedecor and Cochran (1982) and results were expressed as Means \pm standard error (SE). Differences between means in different groups were tested for significance using student $\mathrm{T}$ test as independent $t$ test for all parameters.

\section{Results}

Results of biochemical analysis:

Result of the present study revealed that, $\mathrm{Se}$ supplementation either with / or without Vit. E or organic form had significant $(p<0.05)$ effect on serum total proteins, albumin, and globulins concentrations in all treated groups when compared with the control group. There was significant increase $(\mathrm{P}<0.05)$ in both $\mathrm{GP}_{\mathrm{X}}$ activity and TAC for she camels supplemented with $\mathrm{Se}+$ Vit. E, Se group, and Vit E group compared to control ones. On the contrary, significant $(\mathrm{p}<0.05)$ decrease in serum activity of MDA in all tread groups (Se, Vit $\mathrm{E}$ and $\mathrm{Se}+\mathrm{Vit}$. E) compared with control group was recorded. The results showed significant $(\mathrm{P}<0.05)$ increases in serum $\mathrm{T}_{3}$ concentrations in she camels supplemented with $\mathrm{Se}+$ Vit. E then Se then Vit. E compared to control. While no significant differences were found in serum $\mathrm{T}_{4}$ levels (Table 1 ).

Results of reproductive parameters:

In our study, selenium supplements with or without Vit. $\mathrm{E}$ and a combination of Se / Vit. $\mathrm{E}$ during pre- and postpartum period improve reproductive health status of she camels which manifested by decreasing in the uterine disorders, retained placenta, repeat breeder, ovarian cyst, embryonic death, and abortion when compare to the control group. 
Table (1): Effect of selenium with or without vitamin $E$ supplementation on different biochemical parameters (Mean \pm standard error)

\begin{tabular}{|c|c|c|c|c|}
\hline Parameters & Control & Se & Vit. E & Se/Vit E \\
\hline T.P. $(\mathrm{g} / \mathrm{dl})$ & $5.39 \pm 0.25^{\mathrm{d}}$ & $7.28 \pm 1.13^{\mathrm{b}}$ & $6.42 \pm 0.43^{\mathrm{c}}$ & $7.66 \pm 1.42^{\mathrm{a}}$ \\
\hline Albumin $(\mathrm{g} / \mathrm{dl})$ & $2.67 \pm 0.24^{\mathrm{d}}$ & $3.24 \pm 0.07^{\mathrm{b}}$ & $3.12 \pm 0.22^{\mathrm{c}}$ & $3.65 \pm 0.31^{\mathrm{a}}$ \\
\hline Globulins $(\mathrm{g} / \mathrm{dl})$ & $2.72 \pm 0.01^{\mathrm{d}}$ & $4.04 \pm 0.6^{\mathrm{b}}$ & $3.30 \pm 0.21^{\mathrm{c}}$ & $4.01 \pm 1.11^{\mathrm{a}}$ \\
\hline $\mathrm{GP}(\mathrm{mU} / \mathrm{ml})$ & $196.42 \pm 43.02^{\mathrm{b}}$ & $251.56 \pm 42.21^{\mathrm{a}}$ & $258.65 \pm 33.23^{\mathrm{a}}$ & $256.25 \pm 37.66^{\mathrm{a}}$ \\
\hline $\mathrm{TAC}(\mathrm{mM} / \mathrm{L})$ & $0.458 \pm 0.04^{\mathrm{c}}$ & $0.853 \pm 0.01^{\mathrm{a}}$ & $0.765 \pm 0.1^{\mathrm{a}}$ & $0.831 \pm 0.03^{\mathrm{a}}$ \\
\hline $\mathrm{MDA}(\mathrm{nmol} / \mathrm{ml})$ & $7.67 \pm 4.18^{\mathrm{a}}$ & $5.13 \pm 1.16^{\mathrm{b}}$ & $5.08 \pm 1.47^{\mathrm{b}}$ & $4.57 \pm 2.29^{\mathrm{b}}$ \\
\hline $\mathrm{T}_{3}(\mathrm{ng} / \mathrm{ml})$ & $31.32 \pm 6.25^{\mathrm{d}}$ & $47.09 \pm 7.25^{\mathrm{b}}$ & $41.27 \pm 6.43^{\mathrm{c}}$ & $59.68 \pm 5.91^{\mathrm{a}}$ \\
\hline $\mathrm{T}_{4}(\mu \mathrm{g} / \mathrm{dl})$ & $12.5 \pm 2.19^{\mathrm{b}}$ & $14.6 \pm 3.22^{\mathrm{a}}$ & $14.1 \pm 3.15^{\mathrm{a}}$ & $15.2 \pm 2.9^{\mathrm{a}}$ \\
\hline
\end{tabular}

T. $P=$ total protein, $G P_{X}=$ Glutathione peroxidase, $T A C=$ Total antioxidant capacity, MDA= Malondialdehyde, T3=triiodothyronine $A A, T 4=$ thyroxine. Mean \pm Standard Error with different superscripts $(a, b, c)$ in the same row, are significantly different at $P<0.05$.

Table (2): Incidence number of clinical puerperal complications in different treated groups.

\begin{tabular}{|l|c|c|c|c|}
\hline \multicolumn{1}{|c|}{ Disorders } & Control & Se & Vit. E & Se/Vit. E \\
\hline Retained placenta & 2 & 1 & 1 & 0 \\
\hline Mastitis & 3 & 1 & 2 & 0 \\
\hline Ovarian cyst & 2 & 1 & 2 & 0 \\
\hline Repeat breeder & 5 & 2 & 3 & 1 \\
\hline Metritis & 7 & 2 & 3 & 1 \\
\hline $\begin{array}{l}\text { Embryonic death } \\
\text { of neonates }\end{array}$ & 11 & 3 & 5 & 2 \\
\hline Abortion & 2 & 1 & 1 & 0 \\
\hline
\end{tabular}

\section{Discussion}

Selenium (Se) is known as an essential trace mineral that has several important functions at the level of the cell and organism in animal and human health, and therefore it is relevant to various patho-physiological conditions (Alfthan et al., 2015). The results obtained in the present study showed that serum total proteins (TP), albumin and globulins were significantly increased $(\mathrm{P}<0.05)$ for she camels supplemented with $\mathrm{Se}+$ Vit. E group then Se group then Vit. E group compared with the control group. The results were in agreement with previous findings in she camels Elkhair and Ahmed (2017) and Ahmed and Elkhair (2019). The higher concentration of serum total proteins in the supplemented group could be due to the role of $\mathrm{Se}$ in protein synthesis (AbouZeina et al., 2014). Moreover, $\mathrm{Se}$ is known as an essential 
component of range of selenoproteins (Sherief et al., 2019). Selenoproteins in which selenium is present as selenocysteine, represent an important role in many body functions, such as the production and reproductive properties, the antioxidant defense, and the formation of thyroid hormones (Mehdi et al., 2013).

In the current study, it has shown that supplementation of selenium, vitamin $\mathrm{E}$ and combination of Vit $\mathrm{E} / \mathrm{Se}$ has improved oxidant/antioxidant status through increasing of GPX activity, TAC, and decreasing circulating MDA significantly. The result may be concise with results of Hassan and AbdAllah (2021) and El-Sayed et al. (2020). GPX activity is a powerful indicator of selenium status and reflects the long-term selenium status. Our observations of TAC were in line with the results of Sherief et al. (2019) and Kassab et al. (2020). In the former study, the authors observed a significant elevation in the values of TAC compared with the control ones during the postpartum period which established that, the maternal supplementation of Vit. E/Se during the late stage of gestation and early lactation can ameliorate the antioxidant status. In contrast, the findings of MDA levels were in line with that Sherief et al. (2019) and being away from that reported by Shakirullah et al. (2017) who stated that, supplementation of $\mathrm{Vit} \mathrm{E} / \mathrm{Se}$ at a dose of $50 \mathrm{mg}$ and $0.3 \mathrm{mg} / \mathrm{kg}$ of diet for 4 weeks provoked no significant effect on MDA levels.

When evaluating the effect of antioxidants (Se and / or Vit. E) on the blood activities of thyroid hormones. The present study showed significant $\quad(\mathrm{P}<0.05)$ increases in serum triiodothyronine concentrations in she camels supplemented with $\mathrm{Se}+$ Vit. E then Se group then Vit. E group compared to control. While no significant differences were found in serum thyroxin $\left(\mathrm{T}_{4}\right)$ levels. Similar changes in thyroid hormone activity were in agreed with Abo-Zeina et al. (2014). On the contrary of our result, they found significant increase in plasma T4 levels in neonate's camels like Ahmed and Elkhair (2018) and in lambs Dhari and Kassim (2019). High concentration of thyroxin $\left(\mathrm{T}_{4}\right)$ may be due to the direct action of selenium and its ability to increase glucose metabolism (Mao and Teng, 2013).

The use of Se, vitamin E, or their combination during the transition period was lower the incidence of some reproductive problems compared to the control group. Similar to our study results, supplementation with Se, Vit E and Se/Vit E has 
reduced retained placenta (Yosathai, 2014) and mastitis (Mehdi and Dufrasne, 2016). Selenium and vitamin E as natural antioxidants have an important role in preventing the occurrence of retained placenta, these nutrients increase the activity of neutrophils; enhance their chemotactic effect and phagocytosis of opsonized pathogenic

microorganisms (Joksimović-

Todorović and Davidović, 2013). Adequate Se intake prevents various disorders like early embryonic mortality in neonates (Zarczy 'nska et al., 2013). Se increases proliferation of corpus luteal cells by degrading lipid peroxides resulting in increased progesterone concentration (Kamada and Ikumol, 1997). This improved luteal function will help in preventing early embryonic death (Bajaj and Sharma, 2011). So, Se supplementation improves fertility by reducing embryonic death during the first month of gestation (Mehdi and Dufrasne, 2016). Selenium also has an effect on the decrease in the incidence of metritis and ovarian cysts (Wilde, 2006). The significant increase in the expression of the glutathione peroxidase 1 gene $(G P x l)$ in granulosa cells of healthy follicles points to antioxidant role of GPx1 during the ovarian follicular development (Ceko et al., 2015).

\section{Conclusion}

The present study concluded that supplementation of vitamin $\mathrm{E}$ and/or Se to she camels during the transition period has a vital role, through the changes observed in different oxidative parameters and the enhancement of the metabolic status, which optimizing the reproductive efficiency of she camels.

\section{References}

Abou-Zeina, H.A.A., Nasr, S.M., Nassar, S.A., Genedy, M.A.F. and Mohamed, M.I. (2014): Influence of dietary supplementation with antioxidants on the growth performance, hematological and serum biochemical alterations in Goat Kids. Global Veterinaria, 13, (5): 926-937.

Aghwan, Z.A., Sazili, A.Q., Kadhim, K.K., Alimon, A.R., Goh, Y.M. and Adeyemi, K. D. (2016): Effects of dietary supplementation of selenium and iodine on growth performance, carcass characteristics, and histology of thyroid gland in goats. Animal Science Journal, 87, (5): 690-696.

Ahmed, M.H. and Elkhair, N.M. (2018): Effect of selenium and vitamin $\mathrm{E}$ injection during transition period on growth performance and thyroid hormones profile of neonate 
camels (Camelus dromedarius). The 5th Conference of International Society of Camelids Research and Development (ISOCARD), "Recent advances in camelids biology, health and production", Nov. 11th - 15th, Laâyoune, Morocco.

Ahmed, M.H. and Elkhair, N.M. (2019): Effects of the physiological status and selenium and vitamin $\mathrm{E}$ injection during transition period on serum proteins parameters in camels (Camelus dromedaries) reared under semi-intensive system. International Journal of Research in Medical and Basic Sciences, 5, (1): 14-27.

Alfthan, G., Eurola, M., Ekholm, P., Venäläinen, E. R., Root, T., Korkalainen, K.and Aspila, P. (2015): Effects of nationwide addition of selenium to fertilizers on foods, and animal and human health in Finland: From deficiency to optimal selenium status of the population. Journal of Trace Elements in Medicine and Biology, 31: 142-147.

Ali, A., Derar, D., Alsharari, A., Alsharari, A., Khalil, R., Almundarij, T.I., Alboti, Y. and Al-Sobayil, F. (2018): Factors affecting reproductive performance in dromedary camel herds in Saudi Arabia. Trop. Anim. Health prod., 50: 1155-1160.
Bajaj, N.K. and Sharma, N. (2011): Endocrine causes of early embryonic death: An Overview. Curr. Res. Dairy Sci., 3: 1-24.

Baraka, T.A. (2012): Clinical evaluation of Vitamin A, BCarotene, Vitamin $\mathrm{E}$ and cortisol levels in Health and Selected Diseases in Camels (Camelus dromedarius) in Egypt. J. Am. Sci., 8 (1):106-111.

Braveman, L.E. (1996): Evaluation of thyroid status in patients with thyrotoxicoses. Clinical Chem., 42: 174-181.

Brunetti, C., Di Ferdinando, M., Fini, A., Pollastri, S. and M. Tattini, M. (2013): "Flavonoids as antioxidants and developmental regulators: relative significance in plants and humans," International Journal of Molecular Sciences, vol. 14 , no. 2, pp. 3540-3555.

Ceko M.J., Hummitzsch K., Hatzirodos N., Bonner W.M., Aitken J.B., Russell D.L., Lane M., Rodgers R.J., Harris H.H. (2015): X-ray fluorescence imaging and other analyses identify selenium and GPX1 as important in female reproductive function. Metallomics., (7):6677.

Dhari, E.A. and Kassim, W.Y. (2019): Effect of adding selenium with or without vitamin $E$ and combination of them on some of productive and physiological characteristics of 
awassi lambs. Basrah J. Agric. Sci., 32(2): 61-72.

Dumas, B.T., Watson, W.A. and Biggs, H.G. (1971): Albumin standards and the measurement of serum albumin with bromcresol green. ClinicaChimica Acta., 258: 2130.

Elkhair, N.M. and Ahmed, M.H. (2017): Effects of selenium and vitamin $E$ administration during late pregnancy on the physiological performance of dromedary camels and their neonates reared under semi-Intensive system. Third international science conference of camel research and production. $21^{\text {st }}-23^{\text {rd }}$ November.

El-Sayed A., El-Ashker, M., Ebissy, E. and Ateya, A. (2020). Effect of prepartum vitamin $\mathrm{E}$ and selenium administration on postpartum gene expression and metabolic profile of immune and oxidative markers in Barki ewes. Genetika, 52, (2): $673-688$.

Faye, B., Saleh, S.K., Konuspayeva, G., Musaad,A., Bengoumi, M., Seboussi, R. (2013): Comparative effect of organic and inorganic selenium supplementation on selenium status in camel. Journal of King Saud University - Science.

Flohe, L. and Gunzler, W.A. (1984): Assays of glutathione peroxidase. Methods in Enzymology, 105, 114-120.
Hassan, M.S. and Abd-Allah, E.A. (2021): Impact the effect of vitamin E and Selenium supplementation on oxidative parameters and reproductive efficiency of Egyptian buffaloes. J. Multidiscip. Sci., 3, (1): 16-20. Joksimović-Todorović, M. and Davidović, V. (2013): The effect of antioxidants on preventing the retained placenta in dairy cows. Biotechnology in Animal Husbandry, 29, (4): 581-589.

Kamada, H. and Ikumo, $H$. (1997): Effect of selenium on cultured bovine luteal cells. Anim. Reprod. Sci., 46: 203211.

Kassab, A.Y., Hamdon H., Senosy, W., Daghash, H. and Soliman, A. (2020): Impact of antioxidants supplementation on metabolic status and reproductive performance of Aberdeen cows during seasonal thermal stress in arid subtropical regions. Egyptian Journal of Animal Production, 57, (1): 111.

Koracevic, D. and Koracevic, G. (2001): Total antioxidant capacity (Colorimetric method). J. Clin. Pathol., 54: 356-361. Machado, V.S., Bicalho, M.L., Pereira, R.V., Caixeta, L.S., Knauer, W.A., Oikonomou, G., Gilbert, R.O. and Bicalho, R.C. (2013): Effect of an injectable trace mineral supplement containing selenium, copper, zinc, and manganese on the health and production of 
lactating Holstein cows. Vet. J., 197: 451-456.

Mao, J. and Teng, W. (2013): The relationship between selenoprotein $\mathrm{P}$ and glucose metabolism in experimental studies. Nutrients, 5(6): 19371948.

Maraba, K.P., Mlambo, V., Yusuf, A.O., Marume, U. and Hugo, A. (2018): Extra dietary vitamin E-selenium as a mitigation strategy against housing-induced stress in Dohne Merino lambs: Effect on growth performance, stress biomarkers, and meat quality. Small Ruminant Research Journal, 160: 31-37.

Mehdi, Y. and Dufrasne, I. (2016): Selenium in Cattle: A Review. Molecules, 21: 545550.

Mehdi, Y., Hornick, J.L., Istasse, L. and Dufrasne, I. (2013): Selenium in the environment, metabolism and involvement in body functions. Molecules, 18: 3292-3311.

Ohkawa, H., Ohishi, N. and Yagi, K. (1979): Assay for lipid peroxides in animal tissues by thiobarbituric acid reaction. Analytical Biochemistry, 95, (2): 351-358.

Pourjafar, M., Khalil, B., Saeed, S., Aliasghar, C., Azin, S. and Mojtaba, N. (2014): Correlations between serum trace elements (Selenium, Copper and Zinc) and antioxidant vitamins (Vitamin A,
$\mathrm{E}$ and $\mathrm{C}$ ) in clinically healthy Dromedary Camels. J. Fac. Vet. Med. Istanbul Univ., 40 (1):713.

Sethy, K., Dass, R.S., Garg, A.K., Sahu, S. and Gogoi, S. (2015): Effect of different selenium sources (selenium yeast and sodium selenite) on haematology, blood chemistry and thyroid hormones in male goat (Capra hircus). Indian J. Anim. Res., 49: 788-792.

Shakirullah, S., Muhammad, Q., Sohail, A. and Rifat, U.K., (2017): The effect of vitamin $E$ and selenium on physiological, hormonal and antioxidant status of Damani and Balkhi sheep submitted to heat stress. Applied Biological Chemistry, 60: 585590.

Sherief, M., Abdel-Raheem, G., Mahmoud, B., Walled, S. and Taymour, M. (2019): Influence of vitamin $\mathrm{E}$ and selenium supplementation on the performance, reproductive indices and metabolic status of Ossini ewes. Slovenian Veterinary Research, 56: 353363.

Snedecor, G.W. and Cochran, W.G. (1982): Statistical methods. 7th Edition, the Iowa State University Press, Iowa.

Wilde D. (2006): Influence of macro and micro minerals in the peri-parturient period on fertility in dairy cattle. Anim. Reprod. Sci., (96):240-249. 
Yosathai, R. (2014): Zarczy'nska, K., Sobiech, P., Importance of minerals on Radwi 'nska, J., R. and reproduction in dairy ckawek, W. (2013): Effects of cattle. International Journal of selenium on animal health. J. Science, Environment and Elementol., (18): 329-340.

Technology, 3, (6): 2051-2057.

دور السيلنيوم مع/ او فيتامين هـ فى الوقايه من بعض مشاكل ما قبل الولاده وبعدها فى

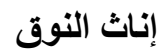

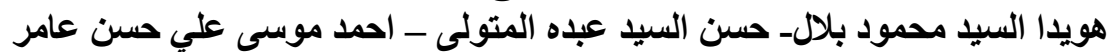

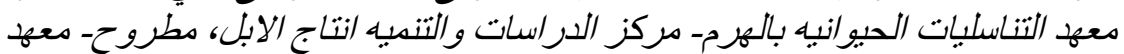

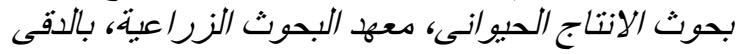

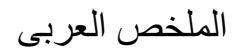

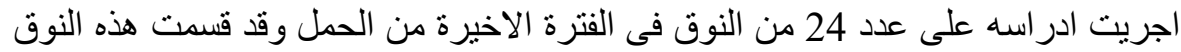

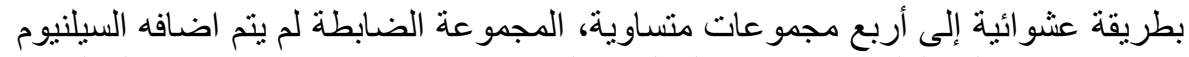

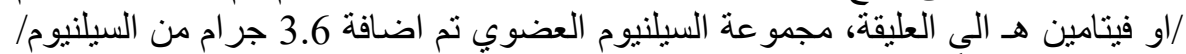

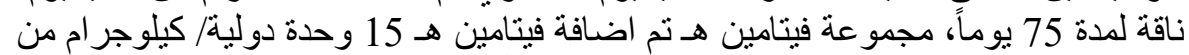

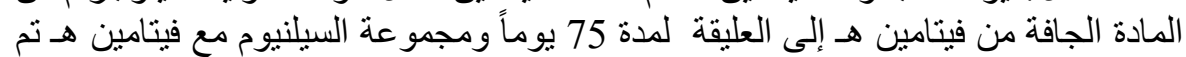

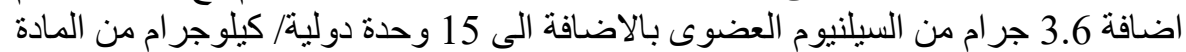

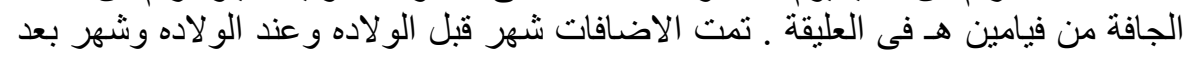

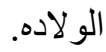

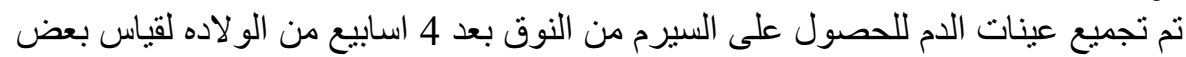

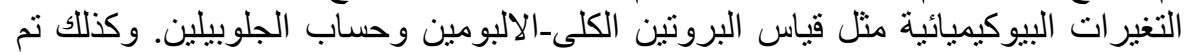

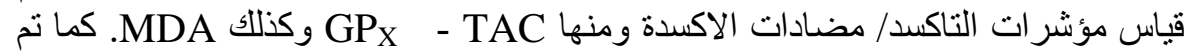

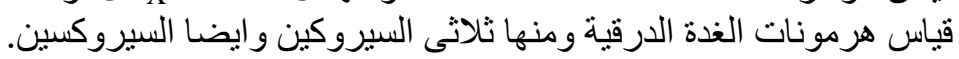

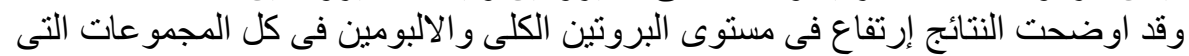

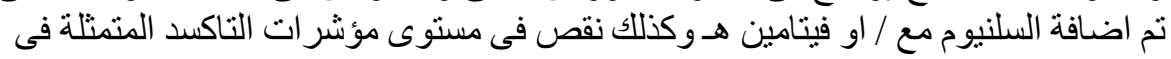

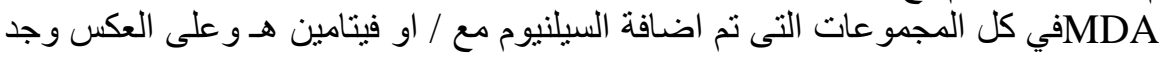

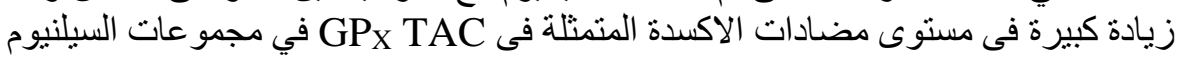

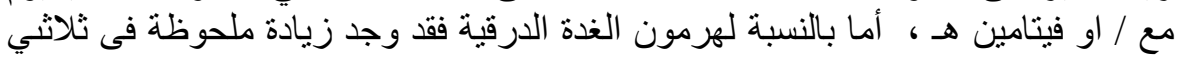

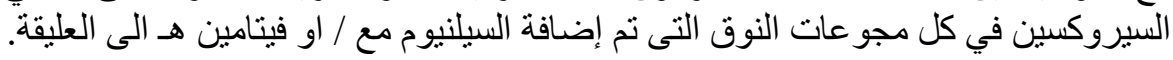

